\title{
Influence of Continental Outflows on Marine Aerosols over Xiaoyangshan Island in the East China Sea: An Episode of Heavy Air Pollution
}

\author{
Yan Zhang, Qi Yu*, Wei-Chun Ma, and Li-Min Chen \\ Department of Environmental Science and Engineering, Fudan University, Shanghai, China
}

Received 3 September 2009, accepted 22 March 2010

\begin{abstract}
Field measurements of aerosols were conducted on Xiaoyangshan Island in the East China Sea in May 2006 to investigate the impact of anthropogenic air pollutants to the coastal environment. MM5/CMAQ was used to model the development of the episode and identify the sources of major ionic species during the episode. The results showed that the major ionic species in TSP were $\mathrm{SO}_{4}{ }^{2-}, \mathrm{NO}_{3}{ }^{-}$and $\mathrm{NH}_{4}{ }^{+}$, which accounted for about $76 \%$ of the total water soluble ions (TWSI). The mean concentrations of $\mathrm{SO}_{4}{ }^{2-}, \mathrm{NO}_{3}{ }^{-}$and $\mathrm{NH}_{4}{ }^{+}$were $20.9,10.4$ and $5.1 \mu \mathrm{g} \mathrm{m}^{-3}$, respectively, and the peak values on a foggy day were $69.87,38.48$ and $22.75 \mu \mathrm{g} \mathrm{m}^{-3}$, respectively. The most abundant ionic species was $\mathrm{SO}_{4}{ }^{2-}$. The increase of $\mathrm{SO}_{4}{ }^{2-}$ concentration was found to be significantly correlated with the decrease of the atmospheric visibility (correlation coefficient $=0.82$ ). Process analysis implied that advection, diffusion and cloud chemical processes contributed to this pollution episode. Backward trajectory analysis revealed that the airflow on the foggy and most polluted day during the sampling campaign was westerly, i.e., from the continent. Both the measured data and modeling results showed that the coastal atmosphere was seriously affected by terrestrial pollutants in the continental outflow.
\end{abstract}

Key words: Marine aerosol, Continental outflow, East China Sea

Citation: Zhang, Y., Q. Yu, W. C. Ma, and L. M. Chen, 2010: Influence of continental outflows on marine aerosols over Xiaoyangshan Island in the East China Sea: An episode of heavy air pollution. Terr. Atmos. Ocean. Sci., 21, 939-953, doi: 10.3319/TAO.2010.03.22.01(A)

\section{INTRODUCTION}

Transport, transformation and deposition of atmospheric aerosols from inland regions to coastal areas have been studied widely (Prospero et al. 1972; Duce et al. 1980; Uematsu et al. 1983; Pavia et al. 1986; Erickson and Duce 1988; Fitzgerald 1991; Smith and Anderson 1992; Kerminen and Wexler 1995; de Leeuw et al. 2000, 2003a, b). Recent field measurements have investigated the chemical composition and transform mechanisms of continental aerosols while they are transported to the marine atmosphere, and found that the mix of marine and continental currents produces unique aerosols in coastal regions (de Leeuw et al. 2001; Pillai et al. 2001; Vignati et al. 2001; Andreae et al. 2003; Marenco et al. 2007).

China's coastline is bordered by the South China Sea, the East China Sea, the Yellow Sea and the Bohai Sea. Coastal areas are the most developed and populated areas

\footnotetext{
* Corresponding author

E-mail:qiyu@fudan.edu.cn
}

in China. Anthropogenic air pollutants emitted from the coastal areas may have significant impact on the chemical composition of marine aerosols. Research on the chemical composition of marine aerosols over the China Sea has been conducted since the 1990s. Zhang and Liu (1994) observed sulfate in atmospheric wet deposition over the Yellow Sea. Gao et al. (1996) and Zhuang et al. (1999a) investigated the characteristics of non-sea-salt sulfate and nitrate over the China Sea. Liu and Zhou (1999) investigated the element profiles of aerosols over the China Sea using data collected on ships. The number of manufacturing facilities has increased rapidly over the last decade. These facilities emit aerosols as well as important precursors such as $\mathrm{SO}_{2}, \mathrm{NO}_{x}$, and $\mathrm{NH}_{3}$.

This paper presents the results of field measurements conducted in May 2006 on Xiaoyangshan Island in the East China Sea which is the important outlet of Asian substances to the west Pacific. We focus on the ionic composition of the coastal aerosols and the formation mechanism of air pollution over the East China Sea. 


\section{METHODS}

\subsection{Sampling}

Field measurements were conducted on Xiaoyangshan Island at about $54.4 \mathrm{~m}$ above sea level $\left(30^{\circ} 38^{\prime} \mathrm{N}, 122^{\circ} 03^{\prime} \mathrm{E}\right)$ in the East China Sea. The samplers were installed at the top of a hill near Xiaoyangshan Meteorological Station. The sampling site was about $500 \mathrm{~m}$ away from the sea, $32 \mathrm{~km}$ away from Shanghai City and about $80 \mathrm{~km}$ from Ningbo City in Zhejiang Province. A site map is provided in Fig. 1.

A medium-flow Andersen TSP collector and an eightstage impactor were used to collect air particles onto Whatman 41 cellulose substrates. The TSP samplings were conducted from 20 May to 1 June 2006. Daily TSP samples were divided into five parts based on the sampling periods: (1) 7:00 - 10:00, (2) 10:00 - 13:00, (3) 13:00 - 16:00, (4) 16:00 - 19:00 and (5) 19:00 - 7:00. Therefore the samples will be named after the sampling date and the intraday sampling sequence in the following sections (e.g., May20-1 refers to the TSP sample collected during 7:00 - 10:00 on May 20). The flow rates for TSP sampling were $110 \sim 180 \mathrm{~L} \mathrm{~min}^{-1}$. Particle sizing samples were collected in varying intervals of $24 \sim 30$ hours at a flow rate of $28.7 \mathrm{~L} \mathrm{~min}^{-1}$. Totally 57 TSP samples and eight sets of sizing samples were collected throughout the sampling period. No samples were collected during 16:00 - 19:00 on May 22 and 16:00 - 07:00 on May 25/26 due to intermittent drizzle, and 07:00 - 10:00 on May 28 due to a power outage.
Local meteorological data were recorded simultaneously. Wind sensors (model: EL15-1/1A and EL15-2/2A) and temperature/humidity sensors (model: LTM8901) were used to measure wind speed, wind direction, temperature, and relative humidity at intervals of 10 seconds. Atmospheric visibility was observed by the local meteorological station.

All the sample filters were cooled immediately after sampling and were stabilized under constant temperature $\left(20 \pm 5^{\circ} \mathrm{C}\right)$ and humidity $(60 \pm 2 \%)$ before and after sampling. All the procedures were strictly controlled to avoid any possible contamination of the samples.

Sample filters and blank filters were extracted ultrasonically with $100 \mathrm{ml}$ water that had been de-ionized to a resistivity of $18 \mathrm{M} \Omega \mathrm{cm}^{-1}$. After passing through microporous membranes (pore size: $0.45 \mu \mathrm{m}$; diameter: $25 \mathrm{~mm}$ ), the filtrates were stored at $4^{\circ} \mathrm{C}$ in clean tubes. Sample analysis was done within 24 hours after filtration. The $\mathrm{pH}$ values of all the filtrates were measured with a $\mathrm{pH}$ meter (model: Orion 818). Ionic species including $\mathrm{SO}_{4}{ }^{2-}, \mathrm{NO}_{3}{ }^{-}, \mathrm{Cl}^{-}, \mathrm{F}^{-}$, $\mathrm{NO}_{2}{ }^{-}, \mathrm{NH}_{4}{ }^{+}, \mathrm{Ca}^{2+}, \mathrm{Na}^{+}, \mathrm{K}^{+}$and $\mathrm{Mg}^{2+}$ were analyzed by Ion Chromatography (IC model: Dionex 500 for anions and Dionex 3000 for cations). The machine consisted of a separation column (Dionex Ionpac AS14 for anions and CS12A for cations), a guard column (Dionex Ionpac AG14 for anions and CG12A for cations), a self-regenerating suppressed conductivity detector (Dionex Ionpac ED40 for anions and ED50 for cations), and a gradient pump (Dionex Ionpac

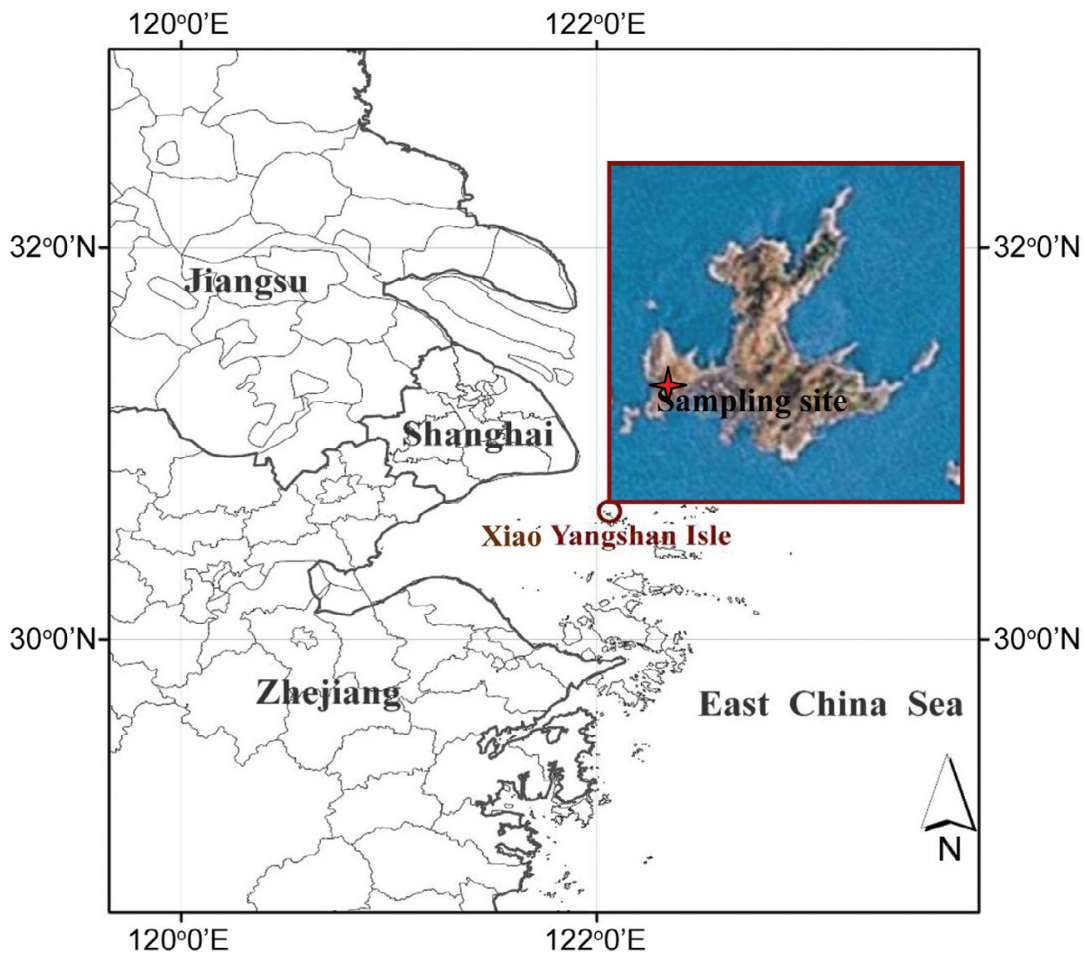

Fig. 1. The sampling site on Xiaoyangshan Island. 
GP40 for anions and GP50 for cations). A gradient weak base eluent $\left(3.5 \mathrm{mM} \mathrm{NaCO}_{3}+1.0 \mathrm{mM} \mathrm{NaOH}+\mathrm{H}_{2} \mathrm{O}\right.$ ) was used for anion detection, and a weak acid eluent $(20 \mathrm{mM}$ MSA) was used for cation detection. The recovery rates of all the ionic species were in the range of $80 \sim 120 \%$ with the relative standard deviations less than $5 \%$.

\subsection{Model}

The mesoscale meteorological model MM5 v3.7 (Grell et al. 1994) and the chemical transport model CMAQ v4.5.1 were used to reproduce the pollution episode. The modeling period was from 0000 UTC 16 May to 0000 UTC 1 June 2006 which covered the 13-day period of our field measurement. Three one-way nested domains were adopted in the MM5 modeling. The grid resolutions were 81, 27, and $9 \mathrm{~km}$ respectively. The two inner domains of MM5 covered and aligned with the CMAQ domains. The inner grid system of CMAQ consisted of $96 \times 96$ cells. It covered the Yangzte River Delta and was centered on Xiaoyangshan Island. Both the inner and outer grid systems of CMAQ had 24 vertical layers with 14 layers in the PBL. The gas-phase chemistry mechanism Carbon-Bond IV and the liquid-phase chemistry mechanism AQ were chosen for the CMAQ simulations. The fourth-generation aerosol module was used, in which three aerosol modes were taken account of: Aitken (0.01 $1 \mu \mathrm{m})$, accumulation (1 - $2.5 \mu \mathrm{m})$, and coarse $(2.5-10 \mu \mathrm{m})$. Advection was calculated using the global mass-conserving scheme (yamo). Horizontal diffusion was calculated according to local wind deformation and vertical diffusion based on the eddy diffusivity theory. The cloud scheme adopted was the RADM-based cloud processor which uses the asymmetric convective model to compute convective mixing. Emission data including $\mathrm{NH}_{3}, \mathrm{SO}_{2}, \mathrm{NO}_{\mathrm{x}}$ and the others were downloaded from REAS (http://www.jamstec. go.jp/frsgc/research/d4/emission.htm), which were further calibrated according to the emission inventories reported in the China Statistical Yearbook on Environment 2006. A sea salt emission scheme (Gong 2003; Zhang et al. 2005) was taken for the inner domain of CMAQ. An initialization run was conducted before each simulation, which started with horizontally uniform and vertically varying clean conditions in the first domain. Initial concentrations were set referring to the literature. Air mass trajectories during the sampling period were modeled with HYSPLIT v4.4 using FNL data (Draxler and Rolph 2003).

\subsection{Meteorological Background}

Typhoon "Chanchu" passed by the provinces to the west of the sampling site two days before our campaign. The northwest part of China was controlled by the cold high pressure system during the campaign.

\subsubsection{Meteorological Condition near Surface}

The 3-hour averaged meteorological data for the sampling period are described in Fig. 2, which include wind, temperature, relative humidity and atmospheric visibility. During the sampling period, there were obvious variations in the wind speed and wind direction (Fig. 2a). Wind speed was greater in the daytime (up to $11.2 \mathrm{~m} \mathrm{~s}^{-1}$ ) than at night. The prevailing wind direction during the campaign was east or southeast, except that the wind direction was southwest/ west on 22/26 May. The temperature was about $18-26^{\circ} \mathrm{C}$. Relative humidity (RH) was above $50 \%$ for all days and reached $100 \%$ occasionally.

Atmospheric visibility almost reached zero on May 23 due to a heavy fog caused by the inverse thermal layer, clear day and the passage of a cold front (Fig. 2c). The coastal region was in the control of high pressure system on that day. The relative humidity was high due to the precipitation on the previous day. The wind speed was low and the increase in air temperature was evident after the passage of the cold front.

\subsubsection{Airflow Trajectories above $500 \mathrm{~m}$}

Daily air mass trajectories of up to $500 \mathrm{~m}$ height above the surface arriving at Xiaoyangshan Island during the sampling period are shown in Fig. 3. The date labels near the start-points of the trajectories in Fig. 3 are the start times. The air masses arriving at the island during the campaign can be divided into two classes, i.e., westerly (SW/W/NW) continental airflow, and easterly (SE/E/NE) marine airflow. The characteristics of the particle concentrations in the corresponding airflows will be discussed below.

\section{IONIC CHARACTERISTICS AND SIZE DISTRI- BUTION}

\subsection{Total Water Soluble Ion Concentrations of TSP}

TWSI concentrations are shown in Fig. 4. TWSI accounted for $24 \%$ of the mass of TSP in all the samples. The concentration values during the campaign ranged from 20.1 to $151.0 \mu \mathrm{g} \mathrm{m}^{-3}$. TWSI concentration stayed low before May 23 and peaked on May 23, then fell gradually until May 28 before it reached sub-highest value on May 29. The prevailing wind direction on days with high TWSI concentration such as on May 23 and 28 was westerly as shown in Fig. 2. The westerly airflow carried abundant continental air pollutants to the marine environment on these days. The sea fog on May 23 led to high RH and fairly weak turbulence that were conducive to the retention and accumulation of pollutants in the marine atmosphere. The relatively low wind speeds afterwards (i.e., from May 23 to 24) prevented the widespread dispersion of the air pollutants over the marine. 
(a)

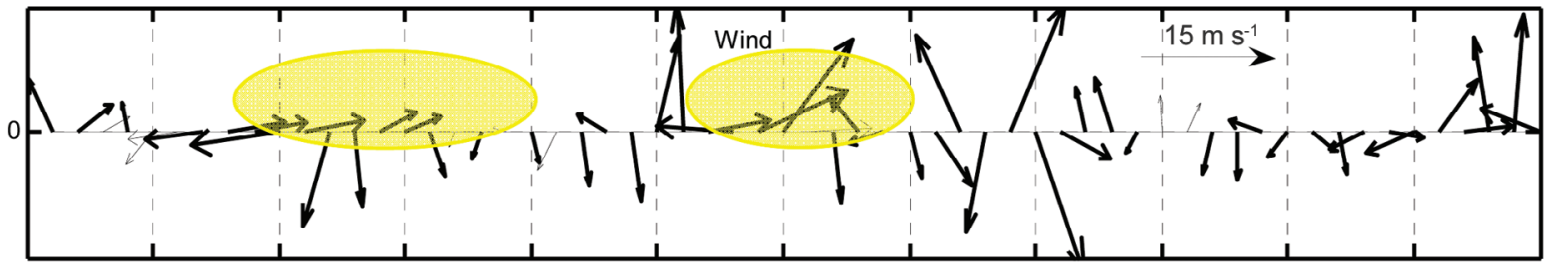

May19-5 May20-5 $\quad$ May21-5 May22-5 May23-5 May24-5 May25-5 May26-5 May27-5 May28-5 May29-5 May30-5 May31-5

(b)

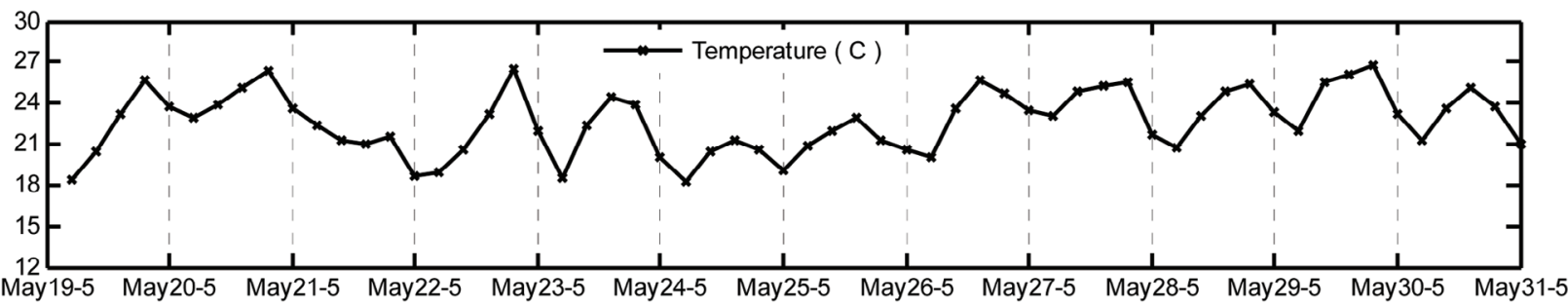

(c)

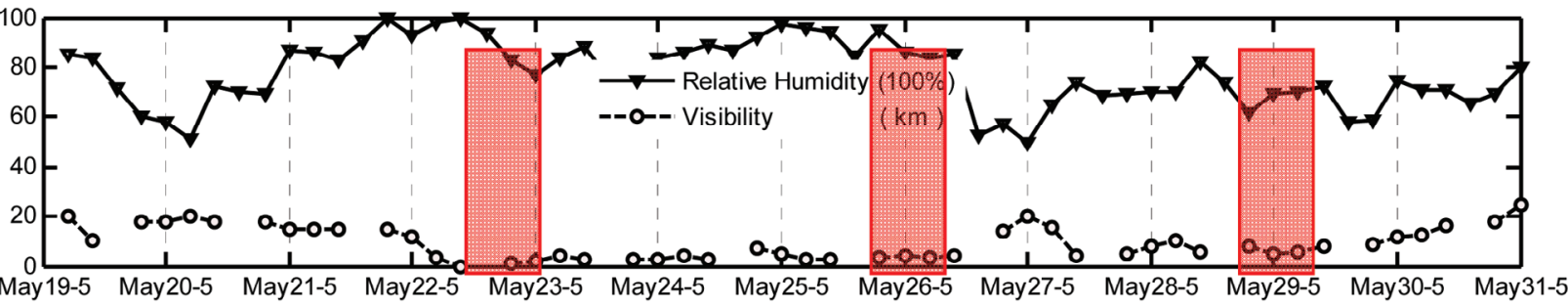

Fig. 2. Three-hour averaged meteorological variables during the sampling period: (a) Wind, (b) Temperature, and (c) RH and Visibility.

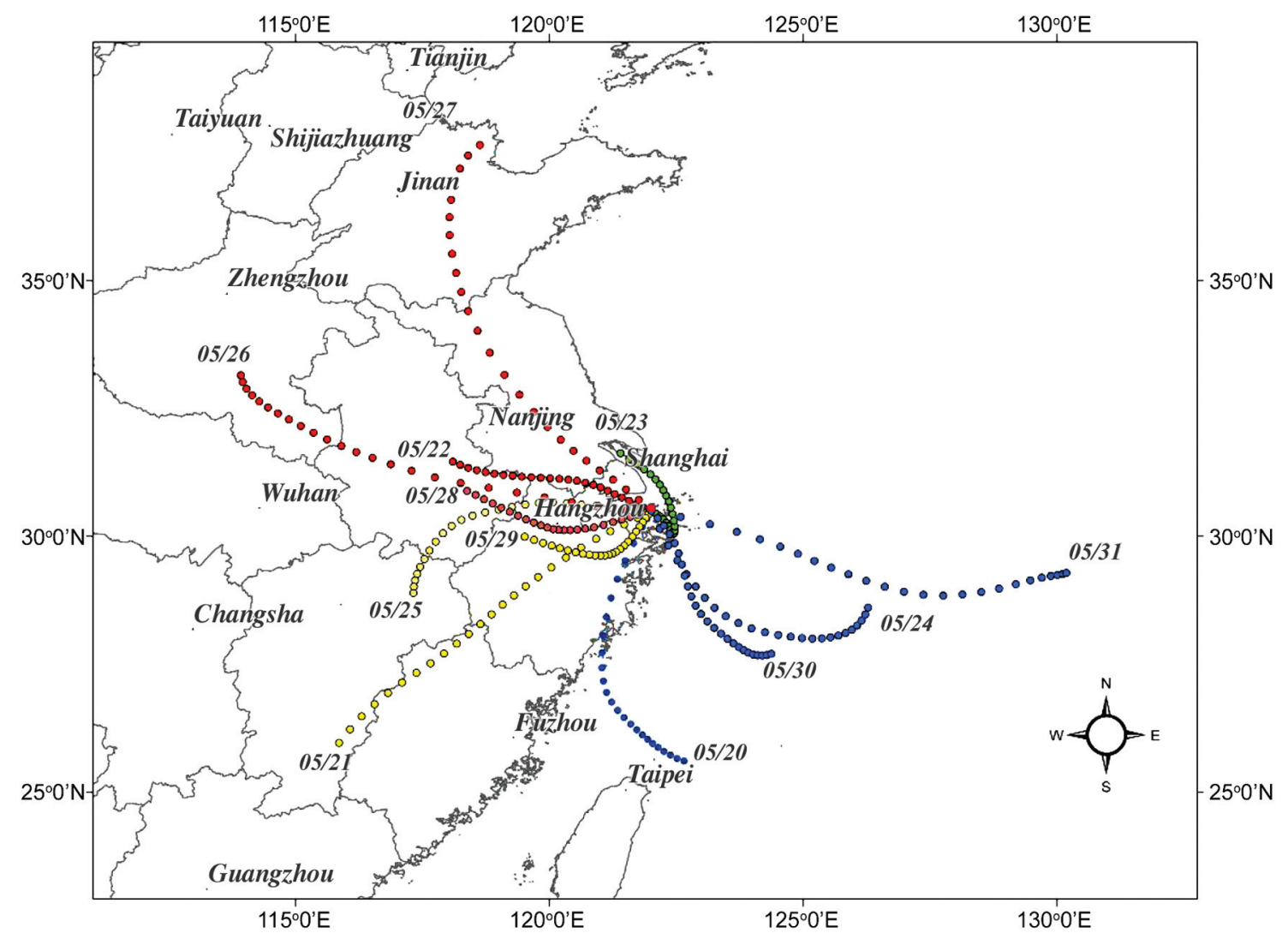

Fig. 3. The 24-hour (starting time: 0000 UT) air trajectories of air masses arriving at Xiaoyangshan Island during the sampling period. The point at $30.63^{\circ} \mathrm{N}, 122.01^{\circ} \mathrm{E}$ represents the sampling site. The hourly footprints of each trajectory are marked by discrete dots. The date labels near the startpoints of the trajectories are the start dates. 


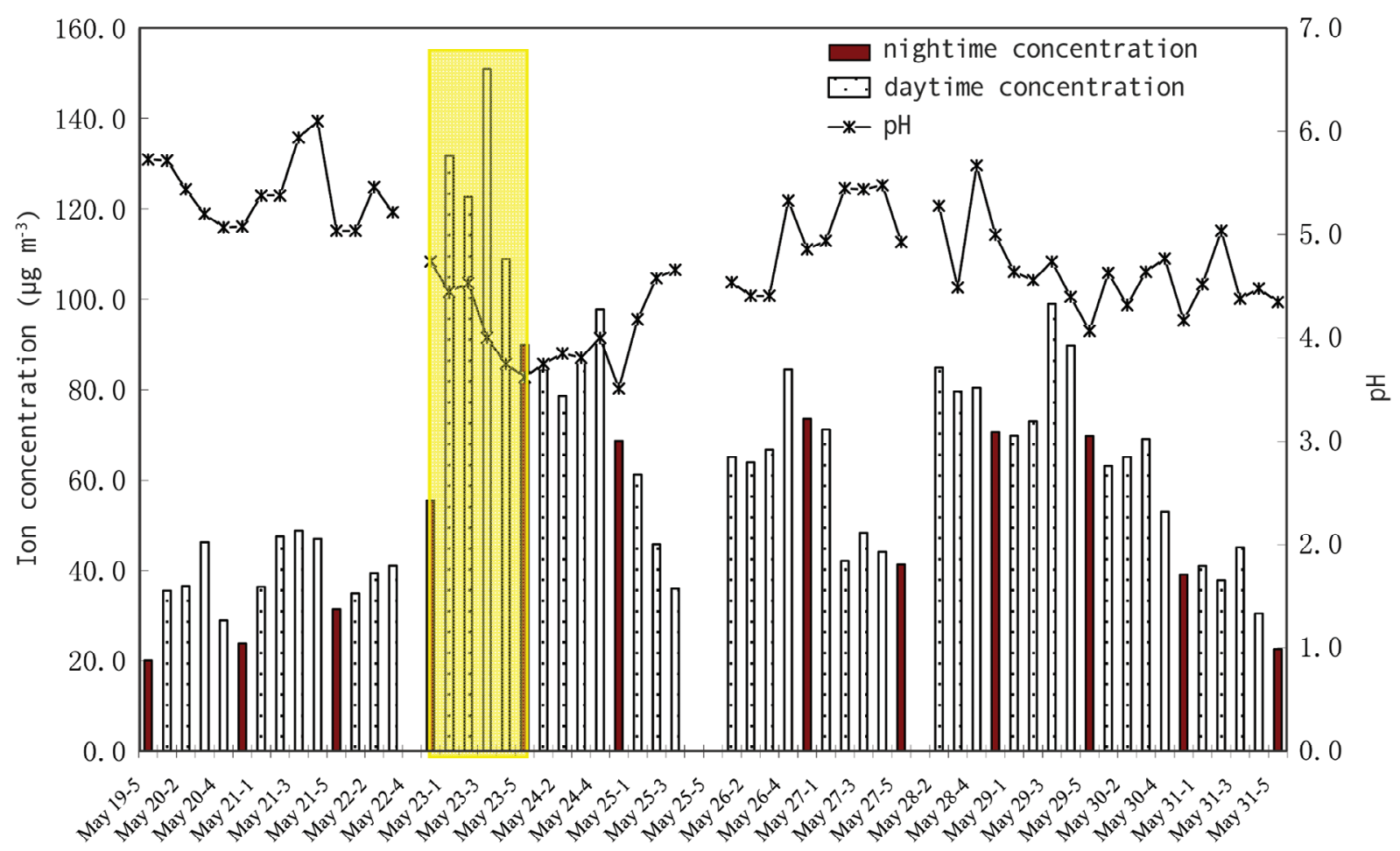

Fig. 4. Temporal variation of the TWSI concentrations in TSP.

The diurnal mean TWSI concentration was $64.8 \mu \mathrm{g} \mathrm{m}^{-3}$, which was higher than the mean value $50.5 \mu \mathrm{g} \mathrm{m}^{-3}$ recorded at night. TWSI concentrations in the afternoon were the highest in the daytime. The mean TWSI concentration of the samples collected during 13:00 16:00 was $68.25 \mu \mathrm{g} \mathrm{m}^{-3}$. The diurnal variation of $\mathrm{SO}_{4}{ }^{2-}, \mathrm{NO}_{3}{ }^{-}$and $\mathrm{NH}_{4}{ }^{+}$concentrations was similar, which infers that strong solar radiation and relatively high temperature in the afternoon may facilitate particle formation.

\subsection{Ionic Species and Acidity of TSP}

The ionic concentrations are shown in Fig. 5. For cations, the main species were $\mathrm{NH}_{4}^{+}, \mathrm{Ca}^{2+}$ and $\mathrm{Na}^{+}$which accounted for $40 \%, 29 \%$ and $17 \%$ of the mass of all cations respectively. For anions, the main species were $\mathrm{SO}_{4}{ }^{2-}, \mathrm{NO}_{3}{ }^{-}$ and $\mathrm{Cl}^{-}$which accounted for $61 \%, 28 \%$ and $9 \%$ of the total anion mass respectively. In all the samples, $\mathrm{SO}_{4}{ }^{2-}, \mathrm{NO}_{3}{ }^{-}$and $\mathrm{NH}_{4}{ }^{+}$were dominant ionic species which represented $76 \%$ of the TWSI mass in average and $87 \%$ on May 23. Maximum concentrations of the ionic species also occurred on May 23, which were $69.87 \mu \mathrm{g} \mathrm{m}^{-3}$ for $\mathrm{SO}_{4}{ }^{2-}, 38.48 \mu \mathrm{g} \mathrm{m}^{-3}$ for $\mathrm{NO}_{3}^{-}$, and $20.75 \mu \mathrm{g} \mathrm{m}^{-3}$ for $\mathrm{NH}_{4}^{+}$. In comparison, the average concentrations of $\mathrm{SO}_{4}{ }^{2-}, \mathrm{NO}_{3}{ }^{-}$and $\mathrm{NH}_{4}{ }^{+}$for all other samples were much lower, which were 20.9, 10.4 and $5.1 \mu \mathrm{g} \mathrm{m}^{-3}$ respectively.

$\mathrm{SO}_{4}{ }^{2-}, \mathrm{NO}_{3}{ }^{-}$and $\mathrm{NH}_{4}{ }^{+}$concentrations on Xiaoyangshan Island were higher compared to the measurements at other
Chinese coastal sites and very close to those measured in the urban area in Shanghai (Li et al. 2005). Gao et al. (1996) found the $\mathrm{SO}_{4}{ }^{2-}, \mathrm{NO}_{3}{ }^{-}$and $\mathrm{NH}_{4}{ }^{+}$concentrations in the TSP samples collected in Xiamen City along the coastal area of the East China Sea were only 18.19, 3.87 and $1.34 \mu \mathrm{g} \mathrm{m}^{-3}$ respectively. $\mathrm{Li}$ et al. (1997) found the $\mathrm{SO}_{4}{ }^{2-}, \mathrm{NO}_{3}{ }^{-}$and $\mathrm{NH}_{4}{ }^{+}$ concentrations were $1.70,9.14$ and $3.01 \mu \mathrm{g} \mathrm{m}^{-3}$ respectively in Dalian City which lies in the coastal area of Bohai Sea. Cheng et al. (2000) reported results of 10.77, 4.21 and $1.39 \mu \mathrm{g} \mathrm{m}^{-3}$ for $\mathrm{SO}_{4}{ }^{2-}, \mathrm{NO}_{3}{ }^{-}$and $\mathrm{NH}_{4}{ }^{+}$respectively in Hong Kong. Meanwhile, ionic concentrations measured in the same season at an urban site in Shanghai were 21.0, 21.7 and $6.96 \mu \mathrm{g} \mathrm{m}^{-3}$ for $\mathrm{SO}_{4}{ }^{2-}, \mathrm{NO}_{3}{ }^{-}$and $\mathrm{NH}_{4}{ }^{+}$respectively (Wang et al. 2006). The concentration levels in different coastal areas imply that the marine atmosphere over the East China Sea was affected more heavily by terrestrial air pollution than other sea areas in China.

$\mathrm{NO}_{3}{ }^{-}$and $\mathrm{NH}_{4}{ }^{+}$concentrations on Xiaoyangshan Island were also higher compared with some European and American coastal sites. For example, de Leeuw et al. (2003b) reported mean concentrations of $2.3-3.7$ and $0.7-1.2 \mu \mathrm{g} \mathrm{m}^{-3}$ for nitrate and ammonium respectively at a ferry site over the North Sea. Yeatman et al. (2001) found concentrations of $0.3-49.0$ and $0.2-18.0 \mu \mathrm{g} \mathrm{m}^{-3}$ for nitrate and ammonium respectively in heavy pollution cases in the coastal area in UK. Evans et al. (2004) reported an average concentration of $3.1 \mu \mathrm{g} \mathrm{m}^{-3}$ for nitrates in the Tampa Bay in Florida.

The temporal variation of $\mathrm{Ca}^{2+}$ concentrations was 
(a)

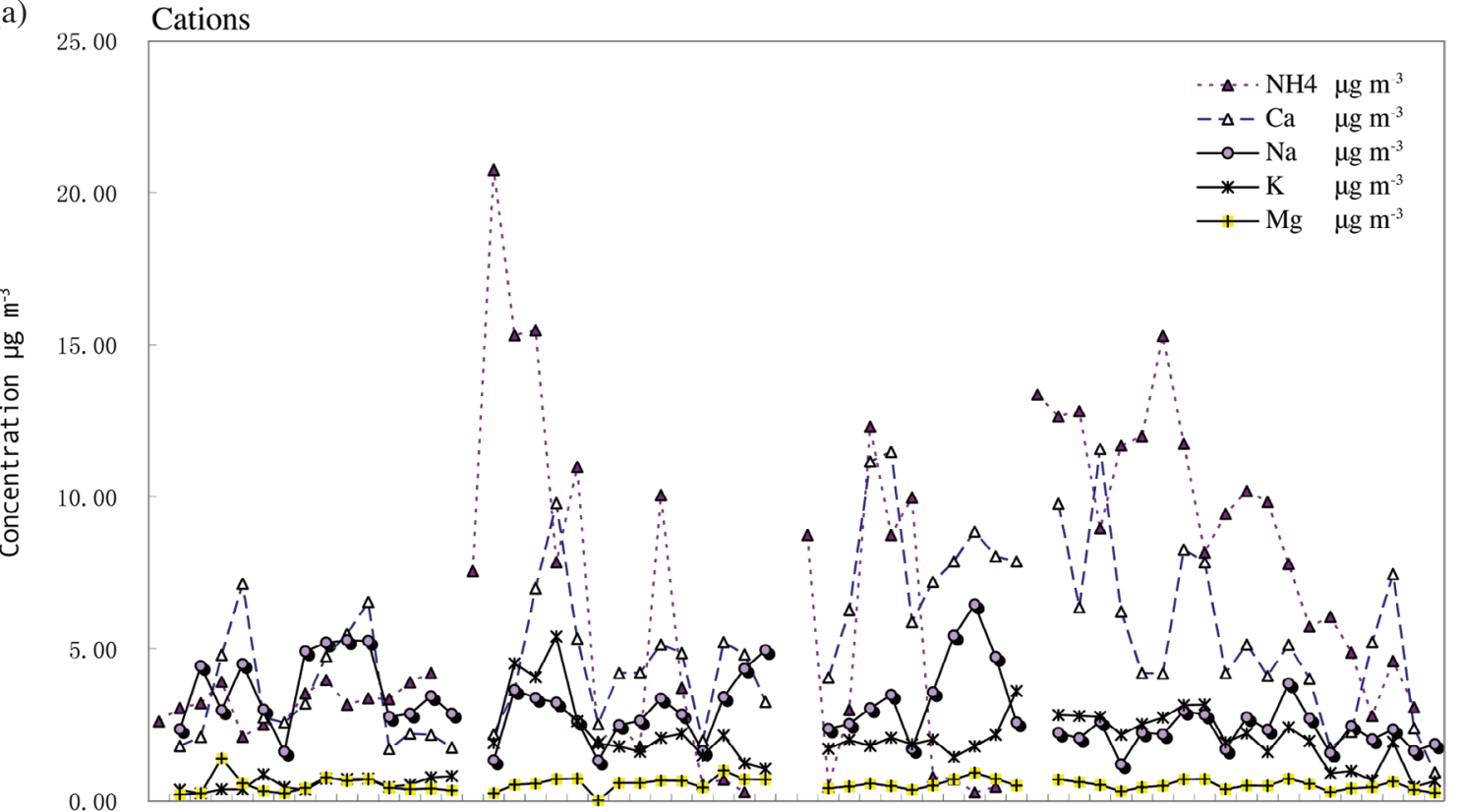

(b)

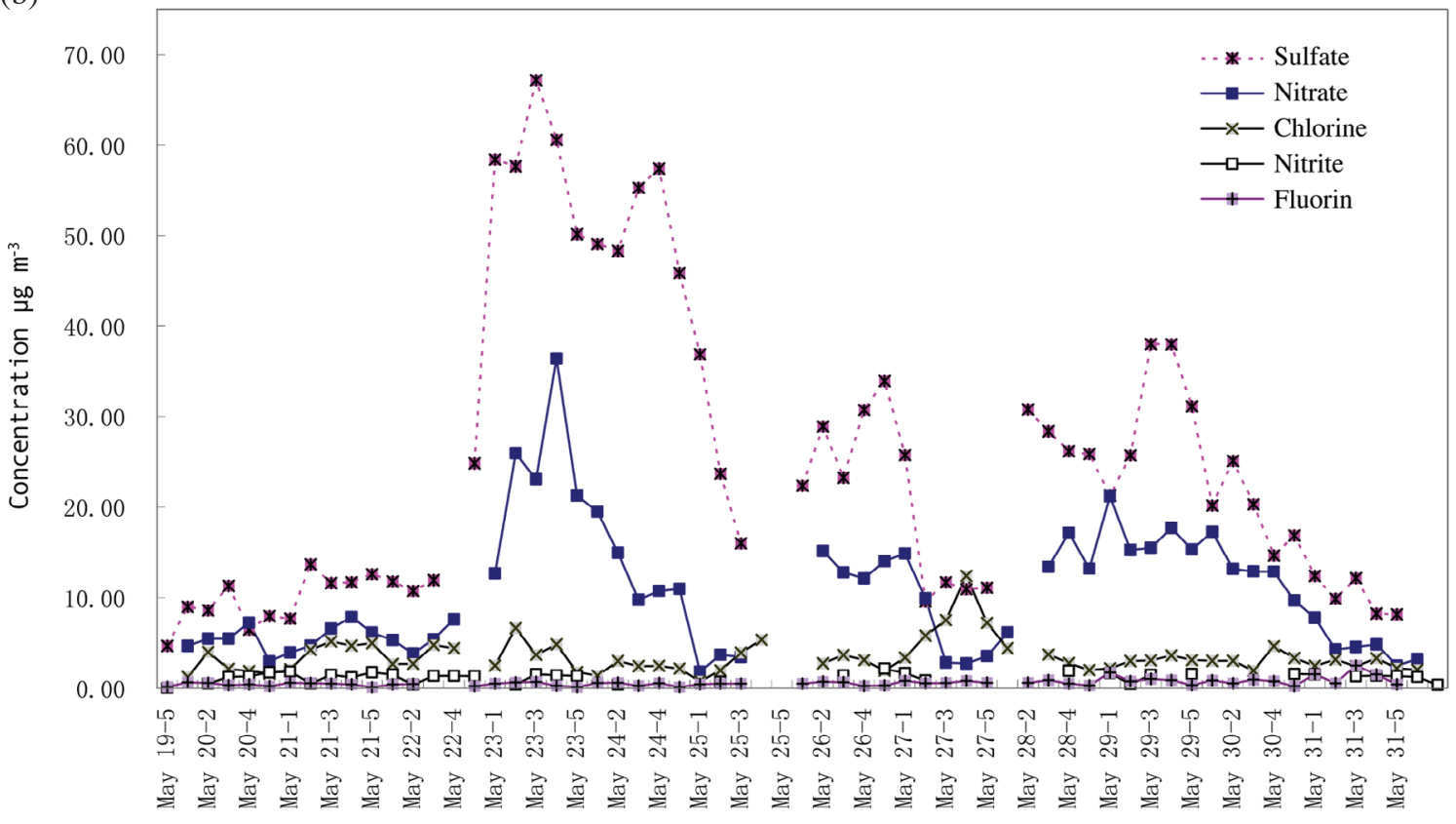

Fig. 5. Temporal variation in (a) cations and (b) anions concentration in TSP.

almost similar to that of TWSI, which indicates that $\mathrm{Ca}^{2+}$ in particles originated largely from the terrestrial sources. However, the concentration of $\mathrm{Ca}^{2+}$ as well as that of $\mathrm{Cl}^{-}$, $\mathrm{Na}^{+}$and $\mathrm{Mg}^{2+}$ experienced an increase on May 27, a windy day. Strong wind shifted more of these elements from the underlying marine surface.

The water-soluble samples were acidic during the sampling period with their $\mathrm{pH}$ values less than 7.0. Generally the $\mathrm{pH}$ value of the aerosol is determined by the balance between the acidic and neutralization components. Both acidic
$\mathrm{SO}_{4}{ }^{2-}$ and alkaline $\mathrm{Ca}^{2+}$ have a sea salt (referred to hereafter as "ss") and a non-sea salt (referred to hereafter as "nss") component (Liss and Galloway 1993). Concentrations of Ss- $\mathrm{SO}_{4}{ }^{2-}$ and $\mathrm{Ca}^{2+}$ in our samples were calculated as 0.252 and 0.044 times of the $\mathrm{Na}^{+}$concentration respectively referring to Keene et al. (1986). The daily mean $\mathrm{pH}$ values and equivalent concentrations of the ionic species are listed in Table 1. It is evident that $\mathrm{pH}$ values on May $23(\mathrm{pH}<4)$ and May 24 were much lower due to the high concentrations of $\mathrm{SO}_{4}^{2-}$ and $\mathrm{NO}_{3}{ }^{-}$. Sulfuric acid was the most important acidic 
Table 1. Daily equivalent concentrations of ionic species and $\mathrm{pH}$ values of TSP.

\begin{tabular}{|c|c|c|c|c|c|c|c|c|c|c|c|}
\hline \multirow{2}{*}{ Date } & \multirow{2}{*}{ pH } & \multicolumn{6}{|c|}{ Equivalent concentration $\left(\mu \mathrm{eq} \mathbf{m}^{-3}\right)$} & \multirow{2}{*}{$\mathrm{NO}_{3}{ }^{-} / \mathrm{nsS}^{-\mathrm{SO}_{4}}{ }^{2-}$} & \multirow{2}{*}{ 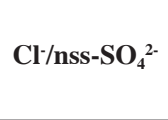 } & \multirow{2}{*}{$\mathrm{NH}_{4}^{+} / \mathrm{nss}^{-\mathrm{Ca}^{2+}}$} & \multirow{2}{*}{$\mathrm{Na}^{+} / \mathrm{nss}_{-} \mathrm{Ca}^{2+}$} \\
\hline & & $\mathbf{N H}_{4}{ }^{+}$ & nss-Ca ${ }^{2+}$ & $\mathbf{N a}^{+}$ & $\mathrm{NO}_{3}{ }^{-}$ & nss-SO ${ }_{4}{ }^{2-}$ & $\mathrm{Cl}^{-}$ & & & & \\
\hline 20-May & 5.17 & 0.15 & 0.16 & 0.12 & 0.10 & 0.20 & 0.08 & 0.49 & 0.43 & 0.95 & 0.71 \\
\hline 21-May & 5.23 & 0.16 & 0.24 & 0.20 & 0.12 & 0.23 & 0.15 & 0.50 & 0.64 & 0.66 & 0.83 \\
\hline 22-May & 4.88 & 0.33 & 0.10 & 0.09 & 0.17 & 0.42 & 0.11 & 0.42 & 0.25 & 3.26 & 0.89 \\
\hline 23-May & 3.79 & 0.72 & 0.22 & 0.10 & 0.39 & 1.18 & 0.10 & 0.33 & 0.08 & 3.28 & 0.45 \\
\hline 24-May & 3.65 & 0.22 & 0.16 & 0.10 & 0.20 & 1.05 & 0.07 & 0.19 & 0.06 & 1.35 & 0.61 \\
\hline 25-May & 4.42 & 0.03 & 0.21 & 0.18 & 0.06 & 0.57 & 0.14 & 0.11 & 0.24 & 0.13 & 0.87 \\
\hline 26-May & 4.68 & 0.41 & 0.35 & 0.10 & 0.25 & 0.65 & 0.11 & 0.38 & 0.17 & 1.19 & 0.28 \\
\hline 27-May & 5.06 & 0.09 & 0.39 & 0.17 & 0.11 & 0.29 & 0.20 & 0.37 & 0.70 & 0.24 & 0.43 \\
\hline 28-May & 4.94 & 0.52 & 0.33 & 0.06 & 0.28 & 0.51 & 0.08 & 0.54 & 0.15 & 1.59 & 0.20 \\
\hline 29-May & 4.25 & 0.58 & 0.25 & 0.09 & 0.29 & 0.67 & 0.11 & 0.43 & 0.16 & 2.28 & 0.36 \\
\hline 30-May & 4.32 & 0.42 & 0.15 & 0.10 & 0.18 & 0.41 & 0.10 & 0.44 & 0.25 & 2.73 & 0.64 \\
\hline 31-May & 4.44 & 0.21 & 0.13 & 0.09 & 0.08 & 0.22 & 0.09 & 0.36 & 0.40 & 1.67 & 0.68 \\
\hline Ave. & 4.57 & 0.32 & 0.22 & 0.12 & 0.19 & 0.53 & 0.11 & 0.38 & 0.29 & 1.61 & 0.58 \\
\hline
\end{tabular}

component because the equivalent molecular concentration of nss- $\mathrm{SO}_{4}{ }^{2-}$ was the highest among all the acidic ions. All the ratios of $\mathrm{NO}_{3}{ }^{-} / \mathrm{nss}-\mathrm{SO}_{4}{ }^{2-}$ and $\mathrm{Cl}-/ \mathrm{nss}-\mathrm{SO}_{4}{ }^{2-}$ were less than 1.0. In terms of neutralization ability, $\mathrm{NH}_{4}{ }^{+}$played a more important role than nss- $\mathrm{Ca}^{2+}$ on most days. The relative contributions of $\mathrm{NO}_{3}{ }^{-}$, nss- $\mathrm{SO}_{4}{ }^{2-}, \mathrm{NH}_{4}{ }^{+}$and nss-Ca ${ }^{2+}$ to TWSI on most days were similar to that observed in sea fog cases in the northern North Pacific by Sasakawa and Uematsu (2005), but contribution of $\mathrm{Cl}^{-}$was found to be more significant in some cases in this study.

\subsection{Size Distribution of Ionic Species}

Figure 6 presents the size distribution of nss- $\mathrm{SO}_{4}{ }^{2-}$, $\mathrm{NO}_{3}{ }^{-}$and $\mathrm{NH}_{4}{ }^{+}$on 23 May 2006. About $40-53 \%$ of the mass of nss- $\mathrm{SO}_{4}{ }^{2-}$ was less than $1.1 \mu \mathrm{m}$. The maximum concentration of nss- $\mathrm{SO}_{4}{ }^{2-}$ was associated with the particles of $0.4-0.7 \mu \mathrm{m}$ in diameter. This is consistent to the results in other studies (Gao et al. 1996). At the same time about 30 $-40 \%$ of the nss- $\mathrm{SO}_{4}{ }^{2-}$ was in the coarse mode. The result is accordant with observations at a sampling site in Hong Kong (Zhuang et al. 1999b).

The size distribution spectrum of $\mathrm{NO}_{3}{ }^{-}$was evidently bimodal. The first peak was associated with particles of 0.4 - $0.7 \mu \mathrm{m}$, similar to the peak of nss- $\mathrm{SO}_{4}{ }^{2-}$. The second peak occurred in the size range of $5.8-9.0 \mu \mathrm{m}$, which may be the result of the displacement reaction associated with coarse particles such as sea salt particles. Moreover, the second peak value was larger than those reported in other studies (Gao et al. 1996; Zhuang et al. 1999b). This may be because our sampling site was far away from the land and the marine atmosphere provided relatively high relative humidity and ample marine materials for the displacement reactions.

The $\mathrm{NH}_{4}{ }^{+}$size distribution on Xiaoyangshan Island was also bimodal with the fine mode of $0.4-0.7 \mu \mathrm{m}$ and the coarse mode of $4.7-5.8 \mu \mathrm{m}$. This is similar to the findings in the South China Sea in Hong Kong (Zhuang et al. 1999b) and in the North Sea in Europe (De Leeuwa et al. 2003a). In addition, the abundance of $\mathrm{NH}_{4}{ }^{+}$in accumulation mode (1.1 - $2.1 \mu \mathrm{m}$ ) was found on May 27 - 28, which was similar to the findings at a UK coastal site (Yeatman 2001). The acceleration of the coagulation processes of $\mathrm{NH}_{4}{ }^{+}$by the continuous onshore wind may be the primary reason for it.

\subsection{Correlation between Ionic Concentrations, Humidity and Visibility}

Correlation with the visibility was analyzed for the main ionic concentration of TSP and the relative humidity. The change of visibility with the concentration of $\mathrm{SO}_{4}{ }^{2-}$ and $\mathrm{RH}$ is shown Fig. 7. Visibility decreased rapidly with the increase of $\mathrm{SO}_{4}{ }^{2-}$ concentration $(r=-0.82)$. However, the concentrations of $\mathrm{NO}_{3}{ }^{-}$and $\mathrm{NH}_{4}{ }^{+}$did not show good correlation with visibility. Visibility was weakly inversely corre- 


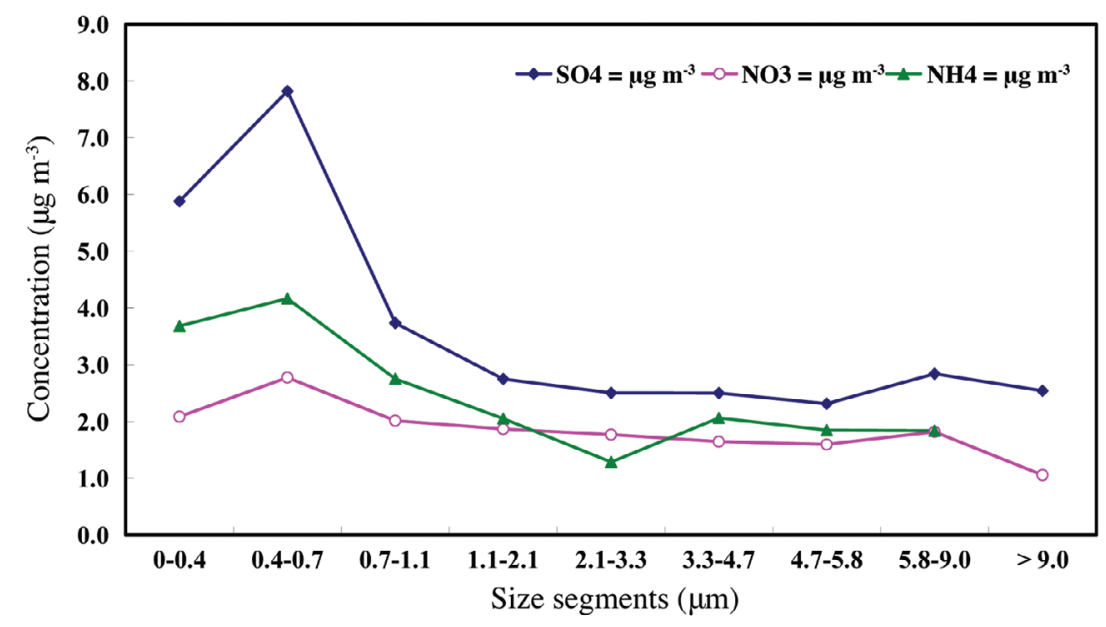

Fig. 6. Particle size distribution patterns: $\mathrm{SO}_{4}{ }^{2-}, \mathrm{NO}_{3}{ }^{-}$and $\mathrm{NH}_{4}{ }^{+}$measured on 23 May 2006.

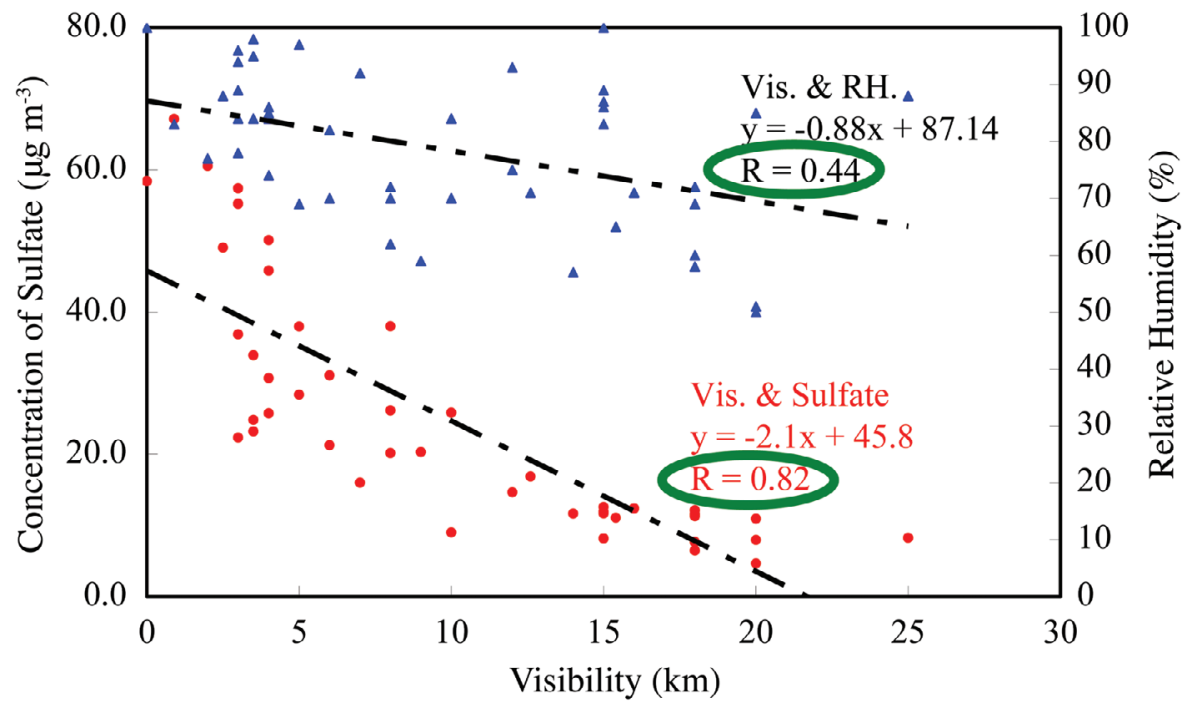

Fig. 7. Correlation of $\mathrm{SO}_{4}{ }^{2-}$ concentration, $\mathrm{RH}$ and visibility on Xiaoyangshan Island.

lated with $\mathrm{RH}(r=-0.44)$. The linear regression between $\mathrm{RH}$ and visibility was done on the all-year base of 2006, which exported a correlation coefficient of -0.40 . It seems that the $\mathrm{SO}_{4}{ }^{2-}$ concentration was a key factor affecting the visibility on Xiaoyangshan Island.

\section{CHEMICAL COMPOSITIONS AND SOURCE IDENTIFICATION}

\subsection{Possible Composition and Formation Mechanism}

The chemical forms of the ionic species in the airborne particles on the Xiaoyangshan Island were identified by multivariate regression statistics with $t$-test. The concentrations of the major chemical species were shown in Table 2, as well as the $t$-test efficiency coefficients and the proportion in TSWI. All the $t$ values were greater than 2.0 show- ing a high regression efficiency. The major chemical forms were $\mathrm{CaSO}_{4},\left(\mathrm{NH}_{4}\right)_{2} \mathrm{SO}_{4}, \mathrm{Ca}\left(\mathrm{NO}_{3}\right)_{2}, \mathrm{Na}_{2} \mathrm{SO}_{4}$ and $\mathrm{NaCl}$. It is clearly that $\mathrm{SO}_{4}{ }^{2-}$ mainly existed as $\mathrm{CaSO}_{4}$ and $\left(\mathrm{NH}_{4}\right)_{2} \mathrm{SO}_{4}$ due to the neutralization reactions and $\mathrm{NO}_{3}{ }^{-}$mainly existed as $\mathrm{Ca}\left(\mathrm{NO}_{3}\right)_{2}$. The concentration of $\mathrm{CaSO}_{4}$ was $32.6 \mu \mathrm{g} \mathrm{m}{ }^{-3}$ accounting for $20 \%$ of TSWI and the concentration of $\left(\mathrm{NH}_{4}\right)_{2} \mathrm{SO}_{4}$ was $23.6 \mu \mathrm{g} \mathrm{m}^{-3}$ accounting for $15 \%$ of TSWI. The main chemical species were similar to those found in the urban atmosphere in Shanghai (Wang et al. 2006) except for $\mathrm{Na}_{2} \mathrm{SO}_{4}$ and $\mathrm{NaCl}$. The chemical species containing $\mathrm{Na}^{+}$ represent the contribution of marine source to the airborne particles.

The possible predominant chemical reactions for the formation of secondary aerosols were summarized as follows. The terrestrial-originated $\mathrm{SO}_{2}, \mathrm{HNO}_{3}$ and $\mathrm{H}_{2} \mathrm{SO}_{4}$ tend to react with aqueous calcium carbonate in airborne parti- 
cles in the wet atmosphere over the continental region and then be transported to the marine environment. Besides, part of gaseous $\mathrm{H}_{2} \mathrm{SO}_{4}$ can be directly transported to the marine environment and react with sea salt (Wolff 1984; Harrison and Kitto 1990; Clarke and Karani 1992; Mamane and Gottlieb 1992; Kerminen et al. 1997).

It has to be mentioned that $\mathrm{NaNO}_{3}$ which is the typical product of the reaction of nitrogen oxides with sea salt aerosols (Pakkanen 1996; Brink 1998; Zhuang et al. 1999a; Evans et al. 2004) was not dominant in this episode. That may imply the predominance of sulfur oxides in the reactions with sea salt aerosols over nitrogen oxides since abundant sulfur oxides have been emitted into atmosphere in the

Table 2. Major water soluble chemical species in atmospheric aerosol over Xiaoyangshan Island*.

\begin{tabular}{|c|c|c|c|c|}
\hline $\begin{array}{c}\text { Major } \\
\text { Chemical. } \\
\text { Species }\end{array}$ & $t$ & $\begin{array}{c}\text { Concentration } \\
\left(\mu \mathbf{g ~ m}^{-3}\right)\end{array}$ & $\begin{array}{l}\text { Std. err. }{ }^{a} \\
\left(\mu \mathrm{g} \mathrm{m}^{-3}\right)\end{array}$ & $\begin{array}{c}\text { Percentage } \\
(\%)\end{array}$ \\
\hline $\mathrm{CaSO}_{4}$ & 5.4 & 32.6 & 2.53 & 20 \\
\hline$\left(\mathrm{NH}_{4}\right)_{2} \mathrm{SO}_{4}$ & 12.9 & 23.6 & 1.49 & 15 \\
\hline $\mathrm{Ca}\left(\mathrm{NO}_{3}\right)_{2}$ & 3.2 & 10.0 & 1.85 & 6 \\
\hline $\mathrm{Na}_{2} \mathrm{SO}_{4}$ & 15.8 & 6.1 & 1.92 & 4 \\
\hline $\mathrm{NaCl}$ & 2.2 & 2.9 & 1.32 & 2 \\
\hline
\end{tabular}

* The number of samples used in the multivariate regression was 129.

a Standard error in concentration.

${ }^{b}$ Percentage of major chemistry species in total water soluble chemical species.
Chinese coastal areas (Akimoto and Narita 1994). The more sulfur oxides react with $\mathrm{NaCl}$ and form $\mathrm{H}_{2} \mathrm{SO}_{4}$, the less nitrogen oxides react with $\mathrm{NaCl}$ and form $\mathrm{NaNO}_{3}$.

\subsection{Source Identification}

\subsubsection{Stationary vs. Mobile Source Contribution}

The mass ratio of $\mathrm{NO}_{3}{ }^{-} / \mathrm{nss}-\mathrm{SO}_{4}{ }^{2-}$ has been used as an indicator of the relative importance of mobile vs. stationary sources of air pollutants in the atmosphere (Arimoto et al. 1996; Yao et al. 2002; Wang et al. 2006). Figure 8 shows the relationships between $\mathrm{nss}_{-} \mathrm{SO}_{4}{ }^{2-}$ and $\mathrm{NO}_{3}{ }^{-}$under different wind directions. The wind directions during the campaign were divided into two groups. One is from the west including southwest, west and northwest airflow (SW/W/NW) and the other is from the east, including southeast, east and northeast airflow (SE/E/NE). The concentration of nss- $\mathrm{SO}_{4}{ }^{2-}$ in the SW/W/NW airflow showed significant correlations with that of $\mathrm{NO}_{3}{ }^{-}$, with the coefficient of determination of 0.93. This indicates that nss- $\mathrm{SO}_{4}{ }^{2-}$ and $\mathrm{NO}_{3}{ }^{-}$were more or less derived from the same continental source. However, in the SE/E/NE airflow weaker correlations existed between nss- $\mathrm{SO}_{4}{ }^{2-}$ and $\mathrm{NO}_{3}{ }^{-}$, with the coefficient of determination of 0.56 . This indicates different chemical processes in the formation and transformation of $\mathrm{SO}_{4}{ }^{2-}$ and $\mathrm{NO}_{3}{ }^{-}$in marine airflow compared to those in continental airflow.

Furthermore the mass ratio of $\mathrm{SO}_{4}{ }^{2-} / \mathrm{NO}_{3}{ }^{-}$which can be represented by the slope of the regression lines was very close to the mole ratio of $\mathrm{SO}_{x} / \mathrm{NO}_{\mathrm{x}}(2: 1)$ from stationary emissions caused by coal burning activities (Kato 1996). It implies that the high concentrations of $\mathrm{SO}_{4}{ }^{2-}$ and $\mathrm{NO}_{3}{ }^{-}$particles were mainly transformed from $\mathrm{SO}_{\mathrm{x}}$ and $\mathrm{NO}_{\mathrm{x}}$ from

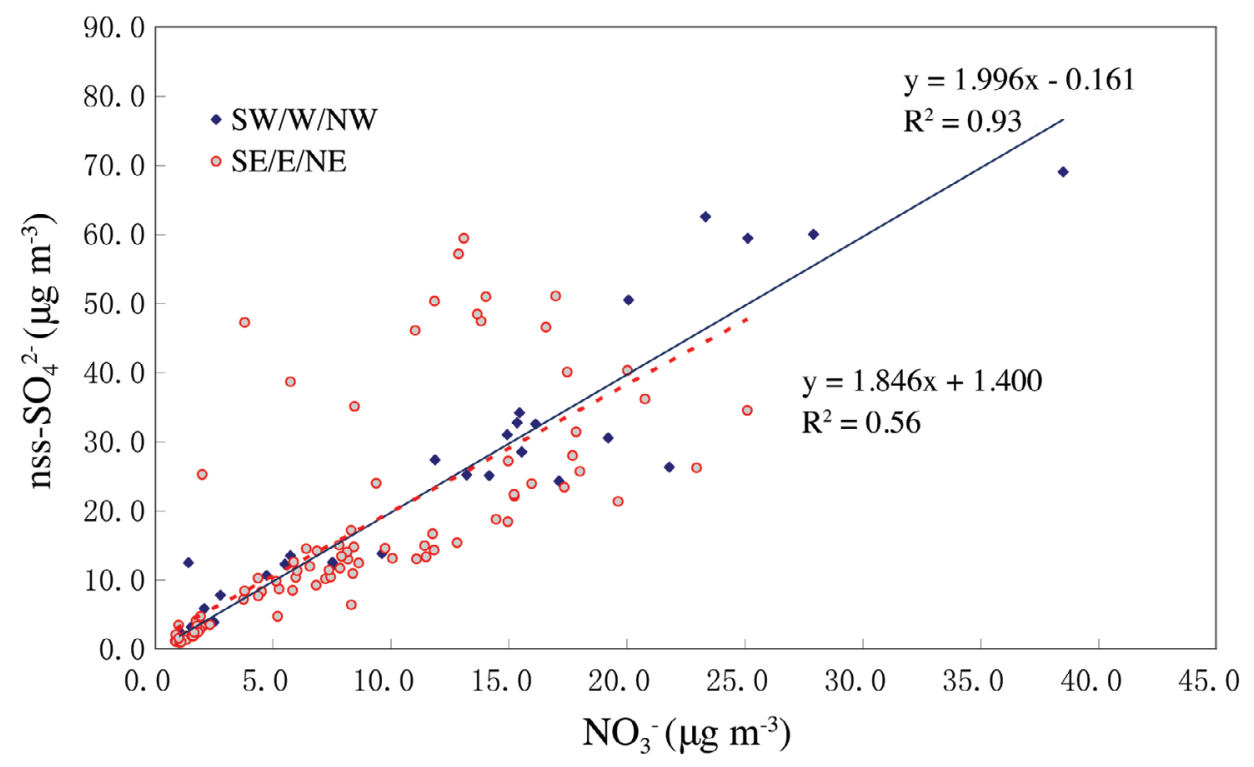

Fig. 8. The relationships between nss- $\mathrm{SO}_{4}{ }^{2-}$ and $\mathrm{NO}_{3}{ }^{-}$in southwest, west and northwest airflow (SW/W/NW) and in southeast, east and northeast airflow (SE/E/NE) periods for all the samples collected at the Xiaoyangshan Island. 
terrestrial industrial sources. This is consistent with the results of previously studies in Shanghai (Wang et al. 2006).

\subsubsection{Modeling the Transport of Terrestrial Air Pollut- ants to the Marine Atmosphere}

Numerical modeling of this episode was done by MM5/ CMAQ described in section 2.2. The correlation coefficient between the modeled with the observed one was 0.74 for wind speed and 0.87 for wind direction, which showed the meteorological conditions could present the factual ones. Figure 9 shows the modeled concentrations of the main ionic species. The model underestimated the $\mathrm{SO}_{4}{ }^{2-}$ and $\mathrm{NO}_{3}{ }^{-}$concentrations due to the relatively low emission inventory of $\mathrm{SO}_{2}$ and $\mathrm{NO}_{x}$ used in the modeling. However, the temporal variations of the modeled concentrations of $\mathrm{SO}_{4}{ }^{2-}, \mathrm{NO}_{3}{ }^{-}$and
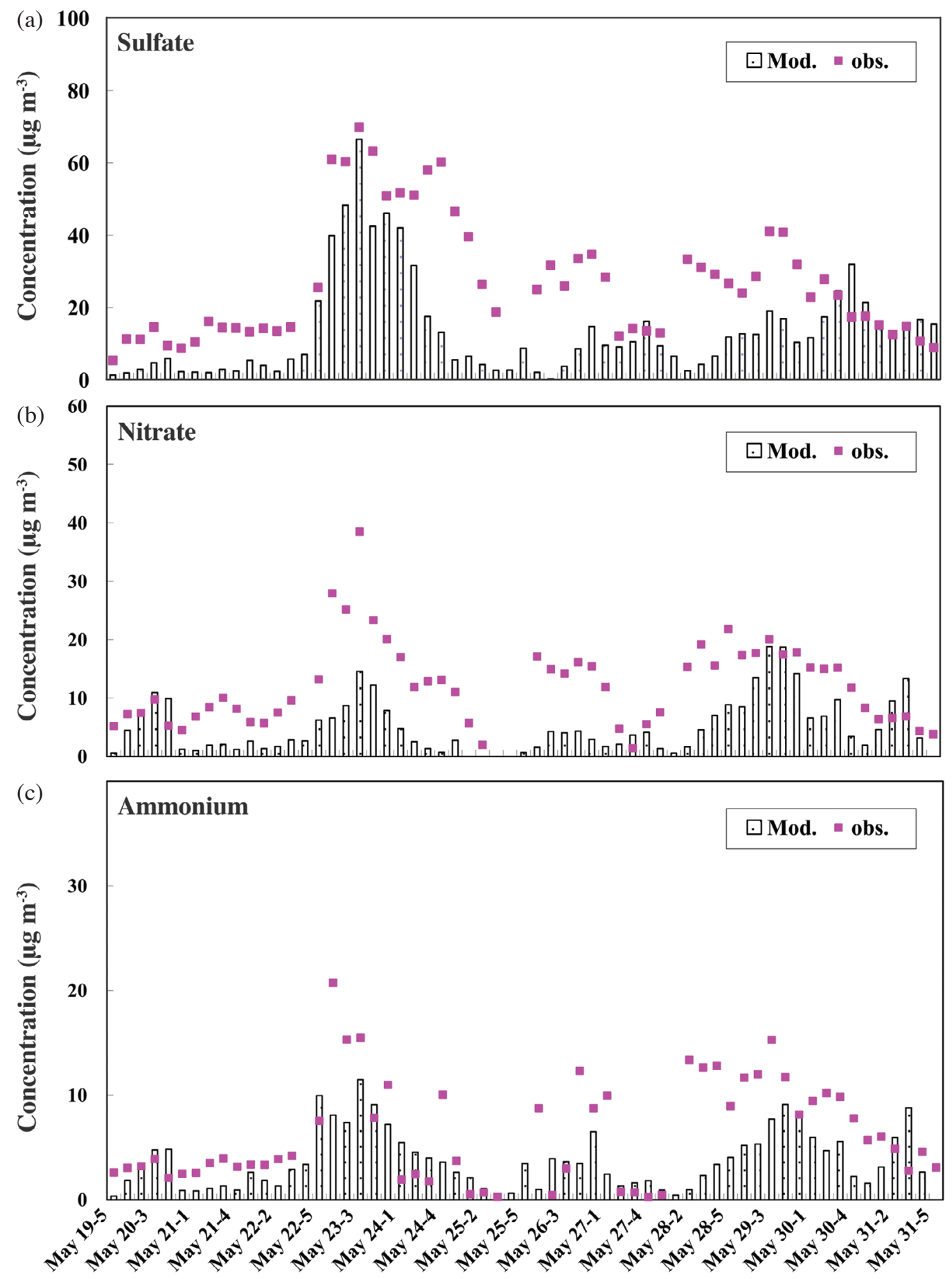

Fig. 9. The comparison of modeled concentrations of (a) sulfate, (b) nitrate, and (c) ammonium with the observed values (unit: $\mu \mathrm{g} \mathrm{m}^{-3}$ ). 
$\mathrm{NH}_{4}{ }^{+}$agreed well with those of the observations.

The spatial distributions of sulfate concentration and the wind field from 03:00 to 15:00 on May 23 were shown in Fig. 10. The pictures show clearly the process of the pollution episode on May 23. The concentration of $\mathrm{SO}_{4}{ }^{2-}$ over the sampling area was less than $5 \mu \mathrm{g} \mathrm{m}^{-3}$ on May 22. Pollutants from inland areas were transported over the East China Sea under the westerly airflow and gradually led to the increase of $\mathrm{SO}_{4}{ }^{2-}$ concentration over the East China Sea on May 23. The area of pollution over the East China Sea started to grow in several hours on May 23 when the wind speed was low and the synoptic condition led to the accumulation of pollutants. The concentration in the center of the polluted area nearly reached $50 \mu \mathrm{g} \mathrm{m}^{-3}$ in the afternoon on May 23 .

\subsubsection{Pollution Budgets}

Process analysis was done to obtain an insight into the pollution budgets of the episode on May 23. Contributions of different processes affecting $\mathrm{SO}_{4}{ }^{2-}$ concentration are presented in Fig. 11. Advection, diffusion and cloud chemical processes were the major contributors to the accumulation of $\mathrm{SO}_{4}{ }^{2-}$ (Fig. 11a) in the daytime on May 23. The contributions of these processes for the peak value of $\mathrm{SO}_{4}{ }^{2-}$ on May (a) May 23 03:00

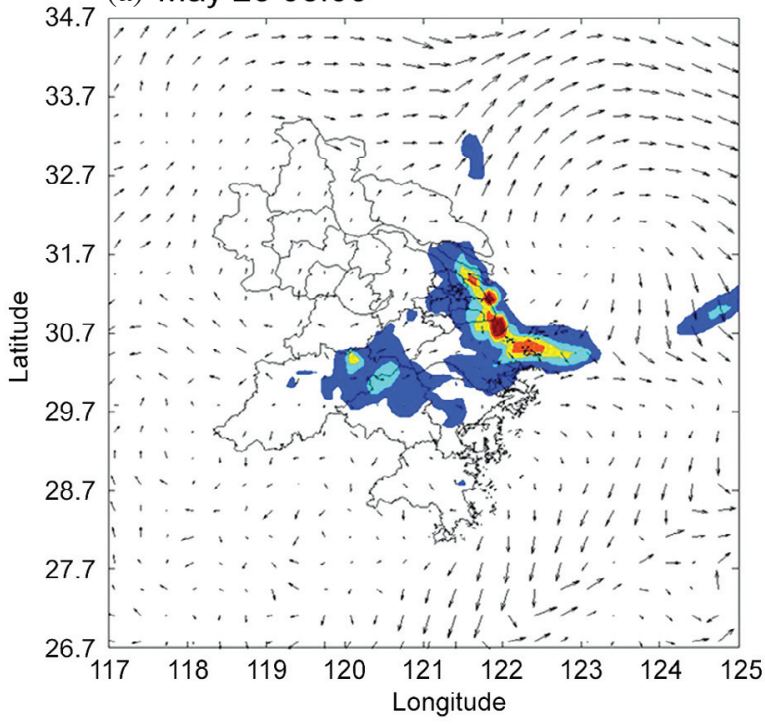

(c) May 23 12:00

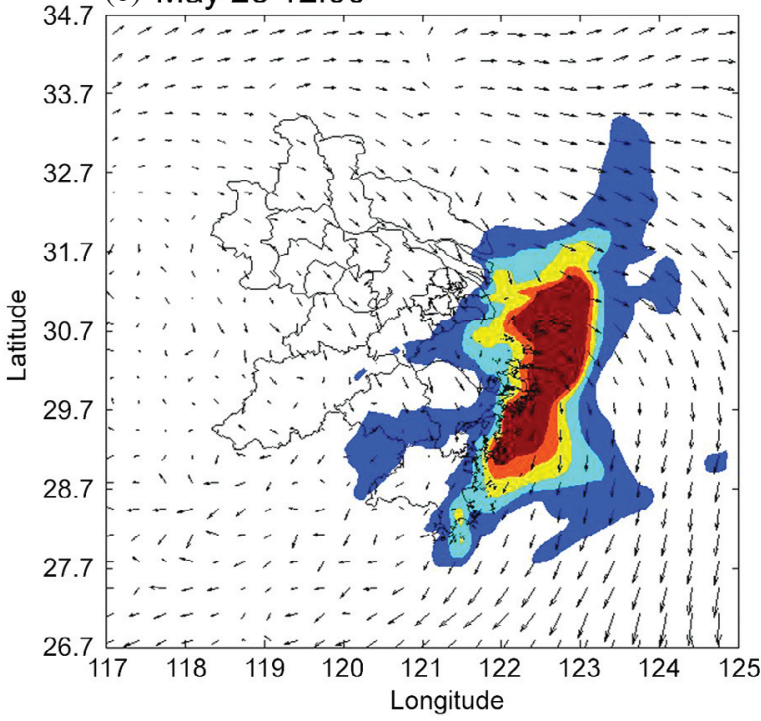

(b) May 23 09:00

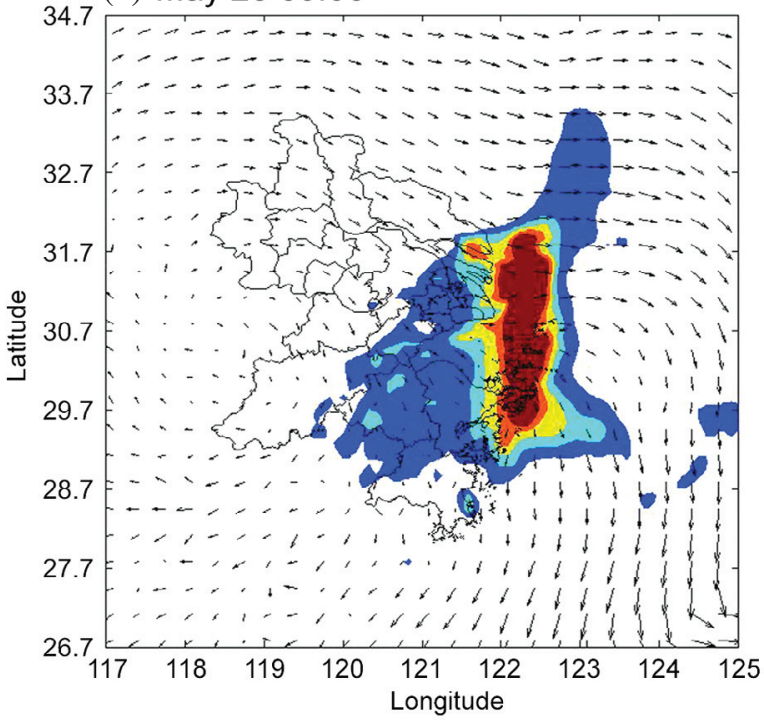

(d) May 23 15:00

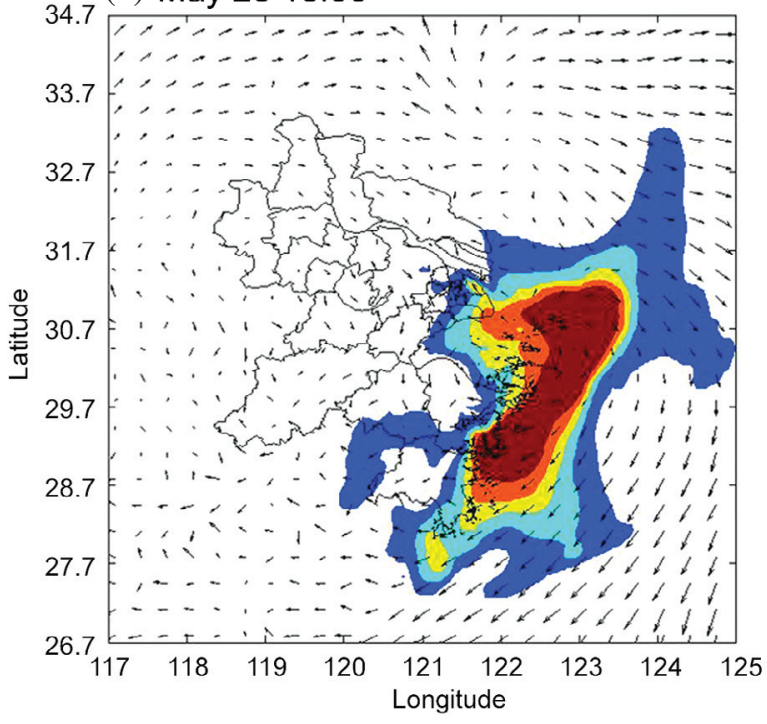

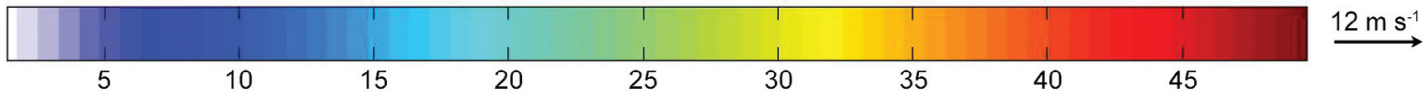

Fig. 10. Concentration distribution and transport processes of $\mathrm{SO}_{4}{ }^{2-}$ in the heavy polluted episode (unit: $\mu \mathrm{g} \mathrm{m}^{-3}$ ). 

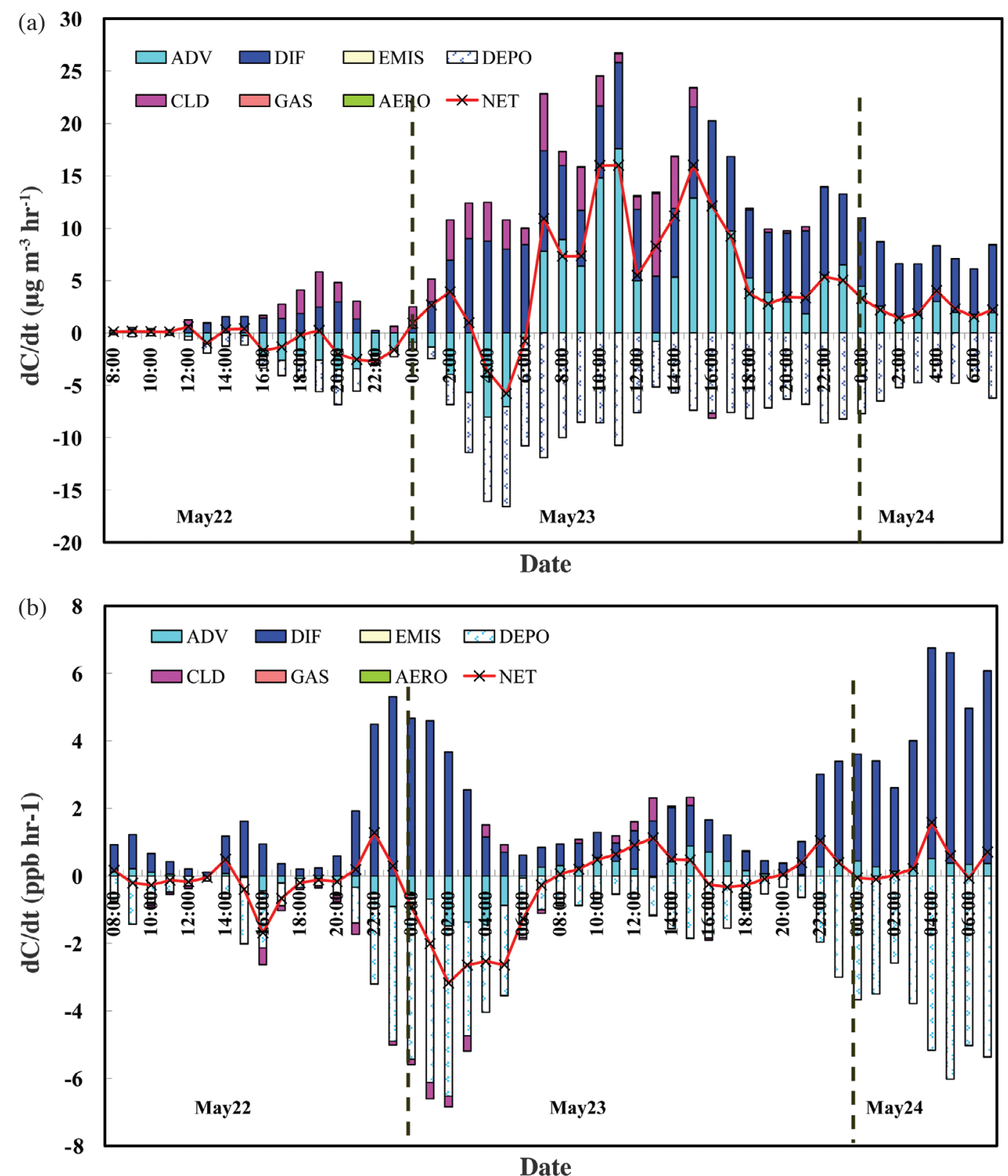

Fig. 11. Hourly pollution process analysis of (a) $\mathrm{SO}_{4}{ }^{2-}$ and (b) $\mathrm{SO}_{2}$ in the polluted episode: ADV- total advection; DIF - total diffusion; EMIS - total emission; DEPO - dry deposition; CLD - liquid-phase chemistry relative to cloud; GAS - gas-phase chemistry; AERO - aerosol chemistry; NET total of the above processes.

23 were about 15,10 and $5 \mu \mathrm{g} \mathrm{m}^{-3} \mathrm{hr}^{-1}$ respectively. Emission of $\mathrm{SO}_{4}{ }^{2-}$ from the sea water was $0.001-0.005 \mu \mathrm{g} \mathrm{m}^{-3} \mathrm{hr}^{-1}$ and almost negligible compared to the other processes. Moreover, there was no evidence that local gas-phase and aerosol chemistry processes had significant impact on the production of $\mathrm{SO}_{4}{ }^{2-}$ in this episode since the concentration of $\mathrm{SO}_{2}$ (Fig. 11b) was fairly low in the daytime.

\section{CONCLUSIONS}

Field measurements were carried out in the East China
Sea in May 2006 to understand the transport of the inland air pollutants to a coastal atmosphere. The concentrations of ionic species ( $20.9 \mu \mathrm{g} \mathrm{m}^{-3}$ for $\mathrm{SO}_{4}{ }^{2-}, 10.4 \mu \mathrm{g} \mathrm{m}^{-3}$ for $\mathrm{NO}_{3}{ }^{-}$and $5.1 \mu \mathrm{g} \mathrm{m}^{-3}$ for $\mathrm{NH}_{4}^{+}$) on Xiaoyangshan Island were much higher than those in some other coastal sites but close to the concentrations measured in the urban area in Shanghai. Size distribution of the major ionic species showed evident shifting of nitrate and ammonium from the fine mode to the coarse mode via sea salt displacement reactions. Atmospheric visibility was found to have significant correlation with anthropogenic sulfate contents in particles. Stationary 
industry sources on the continent could have contributed a lot to the aerosol pollution in the coastal atmosphere. MM5/ CMAQ model system did well in the prediction of coastal aerosol concentration. The modeling results showed the terrestrial pollution sources and the marine meteorological affecting jointly the formation and accumulation of secondary aerosols in the coastal atmosphere. Air pollutants in the westerly airflow had a great impact on the characteristics of aerosol pollution on Xiaoyangshan Island, especially under strong wind cases.

Acknowledgements This work was supported by the National Programs for High Technology Research and Development of China (863 Program) under Grant No. 2008AA06Z401 and 2007AA06A401, and the Foundation for New Teacher by the Ministry of Education under Grant No. 2008024610. We appreciate the help of the Xiaoyangshan Meteorological Station of Shanghai Meteorological Bureau for sharing their sampling site and the local visibility data with us. Sincere thanks to HPCC for support in our computational work.

\section{REFERENCES}

Akimoto, H. and H. Narita, 1994: Distribution of $\mathrm{SO}_{2}, \mathrm{NO}_{x}$ and $\mathrm{CO}_{2}$ emissions from fuel combustion and industrial activities in Asia with $1^{\circ} \times 1^{\circ}$ resolution. Atmos. Environ., 28, 213-225, doi: 10.1016/1352-2310(94)900965. [Link]

Andreae, M. O., T. W. Andreae, D. Meyerdierks, and C. Thiel, 2003: Marine sulfur cycling and the atmospheric aerosol over the springtime North Atlantic. Chemosphere, 52, 1321-1343, doi: 10.1016/S0045-65 35(03)00366-7. [Link]

Arimoto, R., R. A. Duce, D. L. Savoie, J. M. Prospero, R. Talbot, J. D. Cullen, U. Tomza, N. F. Lewis, and B. J. Ray, 1996: Relationships among aerosol constituents from Asia and the North Pacific during PEM-West A. J. Geophys. Res., 101, 2011-2023, doi: 10.1029/95 JD01071. [Link]

Brink, H. M. T., 1998: Reactive uptake of $\mathrm{HNO}_{3}$ and $\mathrm{H}_{2} \mathrm{SO}_{4}$ in sea-salt ( $\mathrm{NaCl})$ particles. J. Aerosol. Sci., 29, 57-64, doi: 10.1016/S0021-8502(97)00460-6. [Link]

Cheng, Z. L., K. S. Lam, L. Y. Chan, T. Wang, K. K. Cheng, 2000: Chemical characteristics of aerosols at coastal station in Hong Kong. I. Seasonal variation of major ions, halogens and mineral dusts between 1995 and 1996. Atmos. Environ., 34, 2771-2783, doi: 10.1016/S 1352-2310(99)00343-X. [Link]

Clarke, A. G. and G. B. Karani, 1992: Characterization of the carbonate content of atmospheric aerosols. J. Atmos. Chem., 14, 119-128.

de Leeuw, G., F. P. Neele, M. Hill, M. H. Smith, and E. Vignati, 2000: Production of sea spray aerosol in the surf zone. J. Geophys. Res., 105, 29397-29409, doi: 10.1029/2000JD900549. [Link]

de Leeuw, G., L. Cohen, L. M. Frohn, G. Geernaert, O. Hertel, B. Jensen, T. Jickells, L. Klein, G. J. Kunz, S. Lund, M. Moerman, F. Müller, B. Pedersen, K. V. Salzen, K. H. Schlünzen, M. Schulz, C. A. Skjøth, L.-L. Sorensen, L. Spokes, S. Tamm, and E. Vignati, 2001: Atmospheric input of nitrogen into the North Sea: ANICE project overview. Cont. Shelf Res., 21, 2073-2094, doi: 10.1016/S0278-4343(01)00043-7. [Link]

de Leeuw, G., C. A. Skjøth, O. Hertel, T. Jickells, L. Spokes, E. Vignati, L. Frohn, J. Frydendall, M. Schulz, S. Tamm, L. L. Sørensen, and G. J. Kunz, 2003a: Deposition of nitrogen into the North Sea. Atmos. Environ., 37, 145165, doi: 10.1016/S1352-2310(03)00246-2. [Link]

de Leeuw, G., L. Spokes, T. Jickells, C. A. Skjøth, O. Hertel, E. Vignati, S. Tamm, M. Schulz, L. L. Sørensen, B. Pedersen, L. Klein, and K. H. Schlünzen, 2003b: Atmospheric nitrogen inputs into the North Sea: Effect on productivity. Cont. Shelf Res., 23, 1743-1755, doi: 10.1016/j.csr.2003.06.011. [Link]

Draxler, R. R. and G. D. Rolph, 2003: HYSPLIT Model. NOAA Air Resources Laboratory, Silver Spring, MD.

Duce, R. A., C. K. Unni, B. J. Ray, J. M. prospero, and J. T. Merrill, 1980: Long-range atmospheric transport of soil dust from Asia to the tropical North Pacific: Temporal variability. Science, 209, 1522-1524, doi: 10.1126/science.209.4464.1522. [Link]

Erickson, D. J. and R. A. Duce, 1988: On the global flux of atmospheric sea salt. J. Geophys. Res., 93, 1407914088, doi: 10.1029/JC093iC11 1p14079. [Link]

Evans, M. C., S. W. Campbell, V. Bhethanabotla, and N. D. Poor, 2004: Effect of sea salt and calcium carbonate interactions with nitric acid on the direct dry deposition of nitrogen to Tampa Bay, Florida. Atmos. Environ., 38, 4847-4858, doi: 10.1016/j.atmosenv.2004.05.046. [Link]

Fitzgerald, J. W., 1991: Marine aerosols: A review. Atmos. Environ., 25, 533-545, doi: 10.1016/0960-1686(91)90 050-H. [Link]

Gao, Y., R. Arimoto, R. A. Duce, L. Q. Chen, M. Y. Zhou, and D. Y. Gu, 1996: Atmospheric non-sea-salt sulfate, nitrate and methane sulfate over the China Sea. J. Geophys. Res., 101, 12601-12611, doi: 10.1029/96JD008 66. [Link]

Gong, S. L., 2003: A parameterization of sea-salt aerosol source function for sub- and super-micron particles. Global Biogeochem. Cycles, 17, 1097, doi: 10. 1029/2003GB002079. [Link]

Grell, G. A., J. Dudhia, and D. R. Stauffer, 1994: A description of the fifth-generation Penn State/NCAR mesoscale model (MM5). NCAR technical Note, NCAR/ TN-389+STR, 117.

Harrison, R. M. and A.-M. N. Kitto, 1990: Field intercom- 
parison of filter pack and denuder sampling methods for reactive gaseous and particulate pollutants. Atmos. Environ., 24, 2633-2640, doi: 10.1016/0960-1686(90) 90142-A. [Link]

Kato, N., 1996: Analysis of structure of energy consumption and dynamics of emission of atmospheric species related to the global environmental change $\left(\mathrm{SO}_{\mathrm{x}}, \mathrm{NO}_{\mathrm{x}}\right.$, and $\mathrm{CO}_{2}$ ) in Asia. Atmos. Environ., 30, 757-785, doi: 10.1016/1352-2310(95)00110-7. [Link]

Keene, W. C., A. A. P. Pszenny, J. N. Galloway, and M. E. Hawley, 1986: Sea-salt corrections and interpretation of constituent ratios in marine precipitation. J. Geophys. Res., 91, 6647-6658, doi: 10.1029/JD091iD06p06647. [Link]

Kerminen, V. M. and A. S. Wexler, 1995: Growth laws for atmospheric aerosol particles: An examination of the bimodality of the accumulation mode. Atmos. Environ., 29, 3263-3275, doi: 10.1016/1352-2310(95)00249-X. [Link]

Kerminen, V. M., T. A. Pakkanen, and R. E. Hillamo, 1997: Interactions between inorganic trace gases and supermicrometer particles at a coastal site. Atmos. Environ., 31, 2753-2765, doi: 10.1016/S1352-2310(97)00092-7. [Link]

Li, D., Y. Zhang, A. Li, Y. Wang, G. Zhang, and Y. Li, 2005: Principal component analysis of atmospheric aerosol $\mathrm{PM}_{10}$ in Wusong Industrial District of Shanghai. Nuclear Techniques, 28, 109-112. (in Chinese)

Li, L., J. Li, G. Gao, G. Liu, and Y. Deng, 1997: Characteristics of aerosol over the coastal region in Dalian. Mar. Environ. Sci., 16, 46-52.

Liss, P. S. and J. N. Galloway, 1993: Air-sea exchange of sulphur and nitrogen and their interaction in the marine atmosphere. In: Wollast, R., F. T. Mackenzie, and L. Chou (Eds.), Interactions of C, N, P and S Biogeochemical Cycles and Global Change, NATO ASI Series, 14. Springer, Berlin.

Liu, Y. and M. Y. Zhou, 1999: Temporal and spatial characteristics of aerosol over the East China Sea. Acta Oceanol. Sin., 21, 38-45. (in Chinese)

Mamane, Y. and J. Gottlieb, 1992: Nitrate formation on seasalt and mineral particles - A single particle approach. Atmos. Environ., 26, 1763-1769, doi: 10.1016/0960-16 86(92)90073-T. [Link]

Marenco, F., F. Mazzei, P. Prati, and M. Gatti, 2007: Aerosol advection and sea salt events in Genoa, Italy, during the second half of 2005. Sci. Total Environ., 377, 396-406, doi: 10.1016/j.scitotenv.2007.02.024. [Link]

Pakkanen, T. A., 1996: Study of formation of coarse particle nitrate aerosol. Atmos. Environ., 30, 2475-2482, doi: 10.1016/1352-2310(95)00492-0. [Link]

Pavia, E. G. and J. J. O'Brien, 1986: Weibull statistics of wind speed over the ocean. J. Clim. Appl. Meteorol., 25, 1324-1332, doi: 10.1175/1520-0450(1986)025<13
24:WSOWSO $>2.0 . \mathrm{CO} ; 2$. [Link]

Pillai, P. S. and K. K. Moorthy, 2001: Aerosol mass-size distributions at a tropical coastal environment: Response to mesoscale and synoptic processes. Atmos. Environ., 35, 4099-4112, doi: 10.1016/S1352-2310(01)00211-4. [Link]

Prospero, J. M. and T. N. Carslon, 1972: Vertical and areal distribution of Saharan dust over the western equatorial North Atlantic Ocean. J. Geophys. Res., 77, 5255 -5265, doi: 10.1029/JC077i027p05255. [Link]

Sasakawa, M. and M. Uematsu, 2005: Relative contribution of chemical composition to acidification of sea fog (stratus) over the northern North Pacific and its marginal seas. Atmos. Environ., 39, 1357-1362, doi: 10.1016/j.atmosenv.2004.11.039. [Link]

Smith, S. D., R. J. Anderson, W. A. Oost, C. Kraan, N. Maat, J. D. Cosmo, K. B. Katsaros, K. L. Davidson, K. Bumke, L. Hasse, and H. M. Chadwick, 1992: Sea surface wind stress and drag coefficients: The HEXOS results. Bound.-Layer Meteor., 60, 109-142, doi: 10. 1007/BF00122064. [Link]

Uematsu, M., R. A. Duce, J. M. Prospero, L. Chen, J. T. Merrill, and R. L. McDonald, 1983: Transport of mineral aerosol from Asia over the North Pacific Ocean. J. Geophys. Res., 88, 5343-5352, doi: 10.1029/ JC088iC09p05343. [Link]

Vignati, E., G. de. Leeuw, and R. Berkowicz, 2001: Modeling coastal aerosol transport and effects of surf-produced aerosols on processes in the marine atmospheric boundary layer. J. Geophys. Res., 106, 20225-20238, doi: 10.1029/2000JD000025. [Link]

Wang, Y., G. Zhuang, X. Zhang, K. Huang, C. Xu, A. Tang, J. Chen, and Z. An, 2006: The ion chemistry, seasonal cycle, and sources of $\mathrm{PM}_{2.5}$ and TSP aerosol in Shanghai. Atmos. Environ., 40, 2935-2952, doi: 10.1016/j.at mosenv.2005.12.051. [Link]

Wolff, G. T., 1984: On the nature of nitrate in coarse continental aerosols. Atmos. Environ., 18, 977-981, doi: 10.1016/0004-6981(84)90073-8. [Link]

Yao, X., C. K. Chan, M. Fang, S. Cadle, T. Chan, P. Mulawa, K. He, and B. Ye, 2002: The water-soluble ionic composition of $\mathrm{PM}_{2.5}$ in Shanghai and Beijing, China. Atmos. Environ., 36, 4223-4234, doi: 10.1016/S13522310(02)00342-4. [Link]

Yeatman, S. G., L. J. Spokes, and T. D. Jickells, 2001: Comparisons of coarse-mode aerosol nitrate and ammonium at two polluted coastal sites. Atmos. Environ., 35, 1321-1335, doi: 10.1016/S1352-2310(00)00452-0. [Link]

Zhang, J. and M. G. Liu, 1994: Observations on nutrient elements and sulphate in atmospheric wet depositions over the northwest Pacific coastal oceans - Yellow Sea. Mar. Chem., 47, 173-189, doi: 10.1016/0304-4203(94) 90107-4. [Link] 
Zhang, K. M., E. M. Knipping, A. S. Wexler, P. V. Bhave, and G. S. Tonnesen, 2005: Size distribution of sea-salt emissions as a function of relative humidity. Atmos. Environ., 39, 3373-3379, doi: 10.1016/j.atmosenv.20 05.02.032. [Link]

Zhuang, H., C. K. Chan, M. Fang, and A. S. Wexler, 1999a: Formation of nitrate and non-sea-salt sulfate on coarse particles. Atmos. Environ., 33, 4223-4233, doi: 10.1016/S1352-2310(99)00186-7. [Link]

Zhuang, H., C. K. Chan, M. Fang, and A. S. Wexler, 1999b: Size distributions of particulate sulfate, nitrate, and ammonium at a coastal site in Hong Kong. Atmos. Environ., 33, 843-853, doi: 10.1016/S1352-2310(98) 00305-7. [Link] 